\begin{tabular}{|l|l|}
\hline $\begin{array}{l}\text { ESCOLA DE COMUNICAÇÃO, } \\
\text { PUCRS }\end{array}$ & $\begin{array}{l}\text { ARTES E DESIGN } \\
\text { FAMECOS }\end{array}$ \\
& $\begin{array}{l}\text { Revidia, cultura e tecnologia } \\
\text { Revista FAMECOS, Porto Al gre, v. 27, p. 1-11, jan.-dez. } 2020 \\
\text { e-ISSN: 1980-3729 | ISSN-L: 1415-0549 }\end{array}$ \\
\hline https://dx.doi.org/10.15448/1980-3729.2020.1.36275 & \\
\hline
\end{tabular}

CIBERCULTURA

\title{
Os memes de Lula na Operação Lava Jato
}

\author{
Memes of Lula in Operation Car Wash \\ Los memes de Lula en Operación Lava Jato
}

\section{Adriano Charles da \\ Silva Cruz ${ }^{1}$ \\ orcid.org/0000-0003-2085-302X adrianocruzUFRN@gmail.com}

Itamar de Morais Nobre orcid.org/0000-0002-5726-8257 itanobre@gmail.com

Recebido em: 11 mai. 2019 Aprovado em: 18 nov. 2019. Publicado em: 17 set. 2020 .
Resumo: O objetivo deste artigo é analisar memes sobre a condução coercitiva do ex-presidente Luiz Inácio Lula da Silva, em 2016. A fundamentação teórico-metodológica está ancorada na Análise do Discurso de linha foucaultiana. O corpus analisado, memes retirados de três sites noticiosos e de jornais online, desconstroem a imagem de Lula graças às suas filiações a formações discursivas opostas a ele. O campo simbólico das imagens torna-se uma arena para a confrontação ideológica e a disputa de sentidos, no contexto sócio-histórico de crise política instaurada pela Operação Lava Jato. Compreendemos que, no cenário da interatividade e da convergência midiática, o dito e o não dito coexistem na superficie dos memes, construindo significações a partir dos jogos de visibilidade e de invisibilidade das imagens. No movimento discursivo das imagens analisadas, observamos a construção de efeitos derrisórios calcados no corpo do petista.

Palavras-chave: Memes. Lula. Operação Lava Jato.

Abstract: This article aims to analyze memes about the bench warrant of former president Luiz Inácio Lula da Silva in 2016. The theoretical and methodological basis is anchored in Foucaultian Discourse Analysis. In analyzed corpus, selected from three news sitesand online newspapers, memes deconstruct Lula's image through affiliations to discursive formations opposed to him. The symbolic field of images becomes an arena for ideological confrontation and dispute over meanings in the socio-historical context of political crisis initiated by Operation Car Wash. We understand that in the scenarium of interactivity and media convergence said and unsaid coexist on the surface of memes. The meaning productions from the play of visibility and invisibility of the images. In the discursive movement of the analyzed images, we observed the construction of derisory effects based on the body of the petista.

Keywords: Memes. Lula. Operation Car Wash.

Resumen: El propósito de este artículo es analizar memes sobre la conducción coercitiva del ex presidente Luiz Inácio Lula da Silva en 2016. El fundamento teórico y metodológico está anclado en el análisis del discurso foucaultiano. En el corpus analizado, seleccionado de tres sitios de noticias y periódicos en linea, los memes deconstruyen la imagen de Lula gracias a sus afiliaciones con formaciones discursivas opuestas al petista. El campo simbólico de las imágenes se convierte en un escenario de confrontación ideológica y disputa sobre los significados en el contexto sociohistórico de la crisis política provocada por la Operación Lava Jato. Entendemos que, en el escenario de interactividad y convergencia de medios, lo dicho y lo no dicho coexisten en la superficie de los memes, construyendo significados a partir de los juegos de visibilidad e invisibilidad de las imágenes. En el movimiento discursivo de las imágenes analizadas, observamos la construcción de efectos irrisorios basados en el cuerpo del petista. Palabras clave: Memes. Lula. Operación Lava Jato. 


\section{Introdução}

"A medusa é quiçá o outro imunológico em sua forma extrema. Constitui uma alteridade radical, que nem sequer se pode olhar, sem sucumbir".

(Han, 2015)

Neste artigo, a partir de uma perspectiva discursiva, analisaremos memes, que circularam nas redes sociais virtuais e nos aplicativos de mensagens para celular, do ex-presidente Luiz Inácio Lula da Silva, após a sua condução coercitiva, em 2016, determinada pelo juiz Sérgio Moro, responsável pela maioria dos processos da Operação Lavajato.

No dia 4 de março de 2016, o ex-presidente foi submetido a um mandado de condução coercitiva no âmbito da Operação Lava Jato². Lula foi forçado ${ }^{3}$ a prestar depoimento à Polícia Federal (PF), no Aeroporto de Congonhas-SP. Tudo foi transmitido ao vivo, especialmente pela Rede Globo de Televisão. Helicópteros de empresas jornalísticas seguiam o carro em que estava o presidente, construindo uma atmosfera cinematográfica, e ocupavam a grade de programação das principais emissoras de TV.

Lula ocupou a Presidência da República por oito anos (2003-2010), elegeu a sua sucessora, Dilma Rousseff - Partido dos Trabalhadores (PT), por duas vezes, e se tornou um dos políticos brasileiros mais conhecidos do mundo. Mas as notícias de escândalos de corrupção envolvendo políticos de diversos partidos e o enquadramento seletivo da mídia construiram uma imagem bem adversa do petista.

Lula foi acusado de obter propinas do esquema de corrupção da Petrobras, que envolveria grandes empreiteiras do Brasil. O Ministério Público e a PF atribuiram a ele a posse de um apartamento triplex no Guarujá/SP, que teria sido reformado com essas vantagens ilícitas, e um sítio em Atibaia/SP.

Foi a primeira vez na história brasileira que um ex-presidente da República foi levado "à vara4" para depor. Isso provocou uma série de discussões mediadas pela imprensa sobre a legalidade da ação e sobre a espetacularização do fato. Além disso, manifestantes contra e a favor de Lula foram às ruas em São Paulo/SP para protestar ou apoiar a ação da Operação Lava Jato.

Embora prevista no artigo n. ${ }^{\circ} 260$ do Código Penal brasileiro, a condução coercitiva só deveria ser aplicada quando o investigado ou a testemunha, após convocação prévia, se recusasse a depor voluntariamente. Mas esse instrumento foi usado de maneira recorrente desde o início da Operação Lava Jato, em 2004, até 2018, quando foi proibida pelo STF. O que também chamou atenção foi o local do interrogatório, fora das dependências policiais.

$\mathrm{Na}$ época o ex-presidente prometeu resistir e anunciou, em discurso após o depoimento, na sede do Partido dos Trabalhadores, em São Paulo, que seria novamente candidato à Presidência em 2018. Em discurso aos apoiadores, Lula se autointitulou como uma cobra jararaca ${ }^{5}$, em uma alegoria da resistência e resiliência encontrada no animal.

Em uma matéria da Folha de S. Paulo, do dia posterior, um manifestante contrário a Lula e ao PT declarou que a condução coercitiva prenunciava "a queda do governo Dilma e do PT" (REVERBEL, 2016, p. A11). De fato, as ações da Lava Jato contribuiram para a corrosão do governo Dilma Rousseff (2016), culminando com a condenação e prisão de Lula (2018) pelo juiz da 13. ${ }^{2}$ Vara Criminal Federal de Curitiba, Sérgio Moro.

O depoimento obrigatório de Lula foi intensamente mediado pela imprensa, com a publicação de reportagens especiais, interpretações e análises, e pelas redes sociais, com a publicação de postagens, memes, comentários. Tudo isso permeado pelo clima de polarização ideológica, esquerda versus direita, intensificada no Brasil, desde a reeleição de Dilma Rousseff, em 2014.

Sustentamos a hipótese de que a Operação

\footnotetext{
2 A origem da Lava Jato está ligada a um esquema de corrupção envolvendo a Petrobras. Em 2004, a Justiça autorizou a quebra do sigilo de telefones de um posto de gasolina em Brasília (DF), para obter informações sobre denúncias de lavagem de dinheiro no Paraná. Essas escutas levaram à prisão do doleiro Alberto Youssef e desencadeou uma série de investigações envolvendo empreiteiros e políticos de diversos partidos

3 Disponivel em: https://politica.estadao.com.br/ao-vivo/operacao-lava-jato-mandado-lula. Acesso em: 31 out. 2019.

4 A expressão foi usada pelo ministro do Supremo Tribunal Federal (STF), Marco Aurélio, que criticou publicamente a medida.

5 Serpente peçonhenta encontrada nas Américas Central e do Sul.
} 
Lava Jato segue a lógica do espetáculo. Com mais de duzentas pessoas investigadas e cerca de uma centena condenada, entre políticos e empresários, a investigação foi construida como um símbolo de combate à corrupção. O juiz federal Sérgio Moro se tornou uma celebridade internacional, tendo a sua imagem sido construida como "herói" pela grande imprensa.

Todavia, as revelações do site The Intercept Brasil ${ }^{6}$, em 2019, apontam a existência de uma articulação entre o juiz e o Ministério Público para prender e incriminar o ex-presidente. Em decorrência disso, há no Supremo Tribunal Federal uma solicitação da defesa do petista pedindo a suspeição do juiz e a anulação da sentença. Lula foi condenado por corrupção passiva e lavagem de dinheiro pelo juiz Sérgio Moro, sendo a sentença referendada pelas segundas e terceiras instâncias do Poder Judiciário.

Antes mesmo das revelações do Intercept Brasil, a Lava Jato já provocava polêmicas pelas suas características de "teatralização" dos processos penais, conforme Gomes (2016). O autor destaca uma série dessas irregularidades, tais como: interceptação telefônica, vazamentos seletivos, gravação e exibição dos interrogatórios e manifestação pessoal dos juizes e promotores nas redes sociais.

A seletividade nas condenações e nas investigações e os métodos midiáticos do aparato jurídico-investigatório foram objetos de debate, tanto no cenário da comunicação como no meio popular. As pessoas investigadas eram expostas à mídia, pré-julgadas pela opinião pública. Exibiam as

"imagens de investigados e réus presos, em regra (desnecessariamente) algemados, sendo transportados em veículos da Polícia Federal, ou até mesmo em gravações de depoimentos que constituirão objeto de acordos de colaboração premiada" (PRADELLA, [2018]).

Em janeiro de 2016, um grupo de mais de cem juristas publicou, em diversos jornais e sites noticiosos (sendo os principais o portal G1, a Agência
Brasil, e o The Intercept Brasil), uma carta aberta com críticas à Lava Jato. No documento, o grupo criticava os vazamentos seletivos à imprensa ${ }^{8}$ e as violações aos "direitos e garantias fundamentais dos suspeitos". Em outro momento, denunciava o chamado "massacre midiático" para pressionar a Justiça a manter prisões provisórias que fazem parte de uma "engrenagem fundamental do programa de coerção estatal à celebração de acordos de delação premiada" (PRADELLA, [2018]).

Alheios às críticas, os principais atores da Operação Lava Jato utilizaram a imprensa e as redes sociais para manter a operação na agenda midiática. Também, adequaram as suas práticas à lógica da mídia. De fato, a "midiatização" (HJARVARD, 2014, p. 53) da Operação Lava Jato foi determinante para a sua permanência na agenda pública, pautando inclusive as propostas das candidaturas presidenciais em 2018.

Figura 1 - Capa da revista Veja, 2016

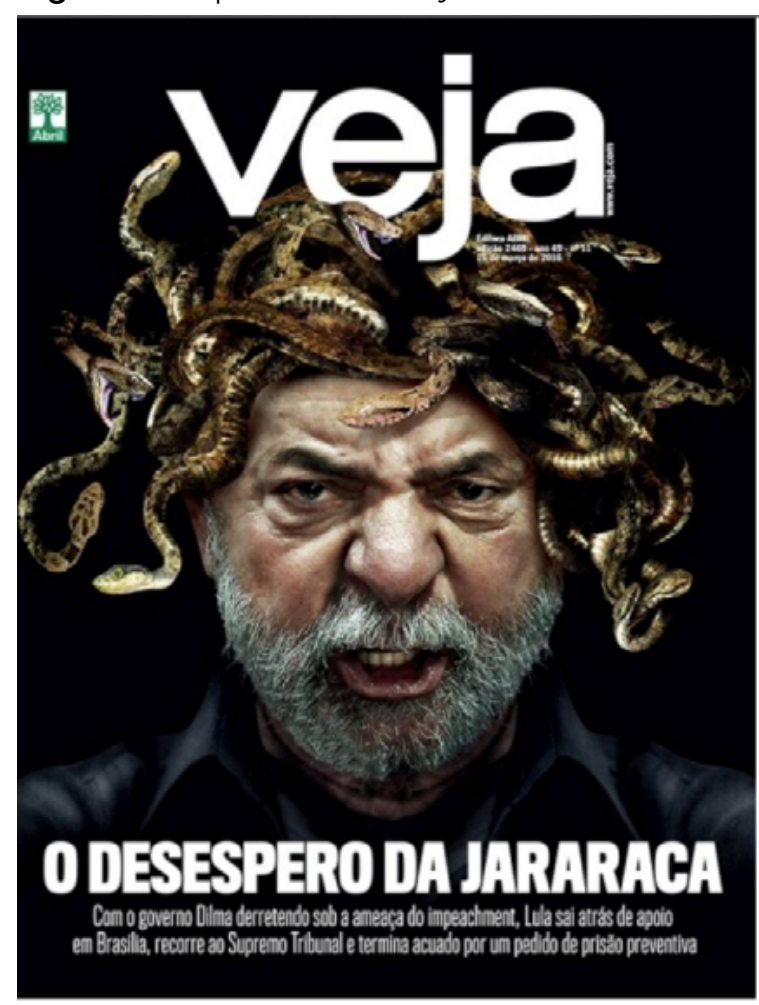

Fonte: Reprodução de imagem da capa da Revista Veja, 12 de março de 2016.9

6 O TIB pode ser acessado pelo endereço: https://theintercept.com/brasil. Acesso em: 5 de set. 2019.

Disponivel em: http://g1.globo.com/politica/operacao-lava-jato/noticia/2016/01/advogados-publicam-manifesto-com-criticas-operacao-lava-jato.html. Acesso em 10 dez. 2019.

8 Quando se fala em vazamento seletivo, diz que há um favorecimento para a negativação pública da imagem de políticos específicos, mais notadamente os pertencentes aos partidos de esquerda

9 Disponivel em: https://veja.abril.com.br/blog/felipe-moura-brasil/o-desespero-da-jararaca/. Acesso em: 12 mar. de 2019. 
Fotografias, textos e outras imagens sobre a condução coercitiva proliferaram no jornalismo e nas redes sociais. Em capa, a revista Veja trouxe a polêmica e o discurso de resistência de Lula, mas o transfigurou intericonicamente em uma medusa (Figura 1). A cara de raiva e o enunciado verbal ${ }^{10}$ complementam a desconstrução do petista.

Imagens como essa foram ressignificadas a partir de estratégias irônicas e por movimentos derrisórios ${ }^{11}$ em memes que proliferam no ciberespaço. Como no exemplo da Figura 2, a seguir:

Figura 2 - Meme Lula/Jararaca

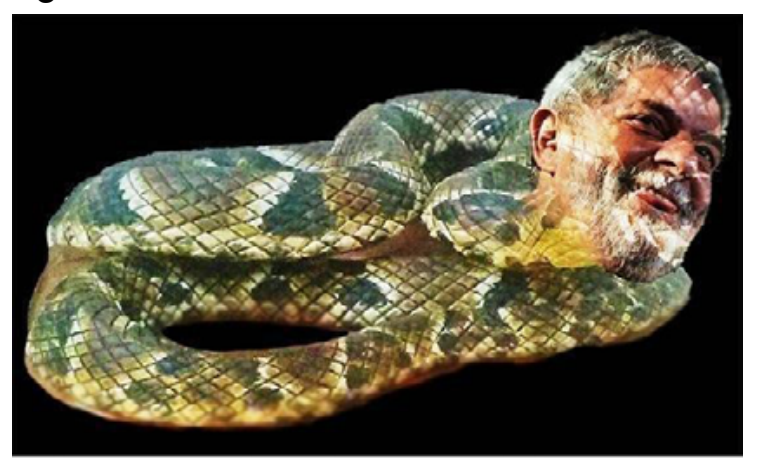

Fonte: Blog Papiro Séc. XXI, de 5 de março de 2016.12

A partir de uma perspectiva discursiva, entendemos que a luta de classes e as microlutas ${ }^{13}$ se materializam em ideologias que, por sua vez, emergem em práticas sociais e discursivas. Esses discursos são práticas ideológicas que tentam manter ou transformar as relações de poder no interior das formações sociais.

As duas imagens monstruosas, da revista e do meme, são materializações de discursos provenientes de ideologias que antagonizam com o lulopetismo. Naquele ano de 2016, os discursos antipetistas circulavam nas redes sociais e na imprensa, convertendo os petistas em símbolos da corrupção que a Operação Lava Jato estava expurgando do País.

É dentro desse cenário, no qual se digladiam forças antagônicas, que temos como objetivo analisar as significações e imagens nele produzidas, tendo como proposta metodológica a Análise do Discurso de linha francesa. Nessa concepção teórica, entendemos que os discursos não se restringem à ordem do linguístico, sendo compreendidos como práticas construídas historicamente. Como ressalta Foucault (2005, p. 56, grifo do autor), é preciso

[...] não mais tratar os discursos como conjunto de signos (elementos significantes que remetem a conteúdos ou a representações), mas como práticas que formam sistematicamente os objetos de que falam. Certamente os discursos são feitos de signos; mas o que fazem é mais que utilizar esses signos para designar coisas. É esse mais que os tornam irredutiveis à língua e ao ato da fala. É esse "mais" que é preciso fazer aparecer e que é preciso descrever.

Os discursos se materializam em textos, imagens, gestos, atitudes, comportamentos a partir das condições sócio-históricas. Outro pressuposto teórico fulcral é que todo o "discurso é interdiscurso", ou seja, não existe discurso adâmico, sem origem histórica. Dessa forma, há, em toda a produção humana, a "memória discursiva" (ORLANDI, 2001, p. 31) que permite a produção de sentido.

Nessa perspectiva, os memes carregam todo um conjunto de ideias, dizeres e silenciamentos que circulam na sociedade e na cultura. Assim, é preciso sempre considerar as condições de existência de cada prática discursiva.

Evidenciamos, agora, o contexto sócio-histórico que proporcionou a circulação desses discursos.

\section{Os memes na cultura da interação}

A interatividade e a convergência dos meios estão à disposição no simples toque na tela do smartphone. As interações em redes pontuam o dia a dia dos sujeitos, surgem novos emissores: a dinâmica da comunicação se complexifica na era do WhatsApp e dos youtubers.

\footnotetext{
10 A referência à cobra foi uma autonomeação de Lula durante o discurso dele na sede do PT: "Se tentaram matar a jararaca, não bateram na cabeça, bateram no rabo". Disponivel em: https://epocanegocios.globo.com/Brasil/noticia/2016/03/se-tentaram-matar-jararaca-nao-bateram-na-cabeca-bateram-no-rabo-diz-lula-em-discurso.html. Acesso em: 24 set. 2018.

11 Os efeitos derrisórios se aproximam da zombaria, conforme Bonaffous (2001). Dessa forma, é uma estratégia discursiva que pretende tornar ridículo ou desprezar o representado.

12 Disponivel em: http://desfragmentopapirosecxxi.blogspot.com. Acesso em 16 ago. 2018

13 Um conjunto de tensionamentos dentro de uma mesma classe social, ou seja, jogos de poder e resistência nas questões de gênero, sexualidades, raças, etnias, entre outras.
} 
Há uma nova "cultura do compartilhamento" (JENKINS, 2009, p. 343), com a formação de comunidades virtuais, segmentação dos públicos, e a mutabilidade do papel consumidor/produtor. É possivel curtir, comentar, compartilhar e, sobretudo, produzir conteúdo e "jogá-lo na rede".

Essa possibilidade de tecer novas interações em rede é apenas uma das faces da sociedade em midiatização. A velocidade de propagação das mensagens, o excesso da informação e de fake news são marcantes.

Longe de proporcionar laços permanentes, a "modernidade líquida" se caracteriza por instabilidade de todas as ordens. Esse tempo de "perigosas incertezas" (BAUMAN, 2001) se alicerça também no individualismo e na transitoriedade.

A "cultura participativa", como anuncia Jenkins (2009) se insere em um contexto de convergências, de produção e distribuição de conteúdos em diversas midias e plataformas. Um video produzido por um usuário do Facebook, por exemplo, pode estar no site do jornal local como um "furo" de reportagem; analisado por especialistas em um programa de TV ou replicado em memes.

O meme é definido como uma unidade de informação cultural transmitida entre individuos ou de uma geração à outra. O termo deriva de uma comparação ao gene biológico, emerge como uma analogia explicativa da propagação dos genes e das ideias (DAWKINS, 2007).

Esses dizeres eram originalmente "histórias, canções, hábitos, habilidades, invenções e maneiras de fazer coisas que copiamos de uma pessoa para outra através da imitação", conforme Blackmore (2000, p. 65). Já na internet os memes serão constituidos predominantemente por mensagens com tons humorísticos ou irônicos de caráter replicador.

Os memes podem ser textos escritos, músicas, videos e outras imagens que circulam na internet e produzem um discurso condensado, apelativo e, na maioria das vezes, humorístico. É importante ressaltar o caráter opinativo e normativo dessas imagens que viralizam na web. Há sempre um discurso de um "deve ser" do meme sobre o mundo
(SHIFMAN, 2014). Por vezes, esses enunciados perdem a autoria, sendo replicados a exaustão.

$\mathrm{Na}$ fronteira entre ficção e referencialidade, os memes podem apresentar imagens absurdas, risiveis ou grotescas. O importante para a construção de sentidos é a sua relação com o contexto histórico-político e com os acontecimentos a que se referem. Dessa forma, a heterogeneidade discursiva transborda em estratégias derrisórias, como a ironia e a paródia.

As imagens foram encontradas por meio de pesquisa no buscador Google, a partir da inclusão dos termos "memes" e "condução coercitiva Lula", no dia 3 de setembro de 2018. O website gerou 62.100 resultados, distribuídos em diversas páginas, entre textos, imagens e outras citações ao tema.

A quantidade de memes nos obrigou a alguns procedimentos metodológicos. De início, restringimos os resultados à primeira página da pesquisa do Google, por sua relevância, que apresentou dez links de sites e blogs jornalísticos. Elegemos os três primeiros sites noticiosos que traziam copilados dos memes, recolhidas em redes sociais ou no WhatsApp. Eram três matérias que reuniam as imagens humorísticas: "Confira memes da condução coercitiva de Lula pela PF", do blog Banda $B$ e "Memes tomam conta da internet após fase da Lava Jato com Lula", da Tribuna Paraná e "Memes viralizam nas redes sociais depois de Lula ser levado pela PF", do site Extra Globo.

Essas matérias geraram um conjunto de 52 memes, embora se tenha algumas repetições de imagens. A partir disso, criamos duas categorias de análises: elegemos os memes que enfocavam Lula diretamente e os que satirizavam algum dos seus aspectos corporais, o que gerou sete imagens distintas. Pelas limitações inerentes ao artigo, selecionamos as cinco mais representativas dessa discursivização ${ }^{14}$.

Identificamos um movimento interdiscursivo que desconstrói Lula a partir da derrisão sobre a ausência do dedo mínimo. Defendemos a existência de uma discursivização sobre o corpo que falta, a mão mutilada carrega uma memória de uma anormalidade, servindo como argumento para uma desqualificação da imagem do ex-presidente.

14 Entendido como o conjunto de operações que constroem sentidos. Esses sentidos são produzidos a partir das relações de força sociais e dos confrontos ideológicos que os sujeitos estão submetidos a partir de seus lugares nas formações ideológicas e sociais. 
Entendemos que a derrisão está ancorada em um processo discursivo de desconstrução da alteridade. Dessa forma, ela se constitui em uma estratégia enunciativa que não se limita ao riso, mas na "combinação do humor e da agressividade que a caracteriza e a distingue, em princípio do puro insulto" (BOUNNAFOUS, 2001, p. 53).

A derrisão se aproxima, pois, da zombaria: "traz consigo uma dimensão de contestação desafiar a ordem estabelecida ou os principios amplamente aceitos em uma sociedade ou grupo" (MERCIER, 2001, p. 10). Portanto, instauram-se, nos memes, jogos irônicos em que são desconstruidos ou ressignificados o acontecimento e a sua memória.

Nas sociedades midiatizadas, os corpos dos políticos são submetidos a inúmeras tecnologias que os tornam atrativos aos eleitores. Em 2002, quando se elegeu presidente pela primeira vez, houve uma série de intervenções no corpo e no discurso de Lula à luz dos ditames do marketing político. Submetido a transformações estéticas, o corpo do ex-sindicalista pôde ser mais aceito socialmente, principalmente pela elite brasileira.

Entretanto, as marcas de sua origem operária serão retomadas em discursos desconstrutores, já que Lula "se limita a maltratar a língua, engolindo os "esses", violentando a sintaxe, forçando erros de concordância" (KUJAWSKI, 2005), segundo artigo do jornal Estado de S. Paulo, de 2005. Essa sua origem na classe operária seria a receita para atrair a atenção do povo, mas, também, roubar a cena em eventos internacionais: "O presidente que cometeu mais gafes na história do Brasil" (AQUINO, 2018), categorizou a revista Época. A "sua voz rouca, com erros de português, metáforas de futebol e piadas do povão era o elo com a massa, na versão do sindicalista exaltado ou do lulinha paz e amor", continua a articulista.

É preciso entender que todo discurso é um lugar de memória: os acontecimentos são lembrados ou esquecidos a partir dos tensionamentos e das lutas sociais. Os deslizes da norma culta gramatical apontam uma origem não burguesa. Além disso, Lula carrega na carne os estigmas de uma deformidade. Essa marca indica a sua histórica filiação à classe trabalhadora, operária e sindicalista, o que gera identificação dos trabalhadores e, também, certa rejeição pela elite.

\section{A desconstrução de Lula nos memes}

A partir de uma genealogia da anormalidade, Courtine (2013) aponta que, no século XIX, na Europa, houve um intenso interesse pelos corpos monstruosos. No imaginário, tudo o que escapava à normatização, seja por falta, excesso, mistura ou separação era considerado desviante.

Essa corporeidade transgressora figurava nos freaks shows, oferecia um espetáculo de diversão das massas, entre homens elefantes, anões, gêmeos siameses e mulheres barbadas. Assim se estabelecia um olhar voyeurista e categorizador dos corpos, como explica Courtine (2011, p. 256): "As festas de feiras do século XIX regurgitavam verdadeiros ou falsos 'selvagens' a exibir para o prazer de multidões 'civilizadas' o grotesco das aparências, a animalidade das funções corporais, a crueza sangrenta dos costumes, a barbárie da linguagem".

É com o auge da biologização que as deformidades humanas serão identificadas e pesquisadas. Dessa forma, se reconhece que tais monstros eram "horrivelmente humanos" (COURTINE, 2011, p. 252). Esses corpos transgressores foram incorporados a um saber médico-biológico e os zoológicos humanos a partir de pareceres científicos foram então interditados.

Essa foi, para Courtine (2013, p. 118), uma "mudança de sensibilidade", pois lá onde se via apenas monstruosidade se começou a perceber uma enfermidade. A partir do discurso médico-jurídico era preciso explicar as raízes patológicas e os desvios dos seres humanos. Em sintese: identificar, corrigir e normatizar.

Entretanto, era preciso saciar o desejo de vere contemplar os seres abjetos. Relegado às imagens ficcionais, o espetáculo da deformidade (COURTI$\mathrm{NE}, 2013$ ) tornou-se mediado pelo aparato técnico, cinema e TV. Frankenstein, Drácula, Freaks, King Kong, Medusas, imagens partidas, os "outros" de nós mesmos. Defendemos que essa estética da monstruosidade também será retomada, via memória, em diversos produtos da mídia: anúncios publicitários, memes, capas de revistas etc. 
Em Os anormais, Foucault (2001) buscará investigar a mudança da transgressão monstruosa ao domínio da conduta, ou seja, a esfera da justiça e do direito penal.

É nessa "sociedade disciplinar" que os indivíduos estarão sujeitos à vigilância constante, os seus corpos e rostos são examinados e normalizados por meio das instituições como as escolas, fábricas, hospitais e prisões.

Em outros momentos, como no nazismo, o poder/saber médico construiu teorias eugênicas e racistas que buscaram medicalizar e exterminar os corpos transgressores. A "massa de desviantes ${ }^{15 "}$ (FOUCAULT, 1987), composta por loucos, vagabundos, deliquentes, será submetida à violência do fascismo e ao controle de um biopoder.

Na passagem da sociedade disciplinar para a de "controle" (DELEUZE, 1992), a discursividade estética levará também às práticas de transformações corporais, desde o body bulding nas academias às cirurgias plásticas.

Embora, o preconceito com os "corpos diferenciados" (OLIVEIRA, 2013) persista e, por vezes, se materialize nas linguagens verbais e não verbais, as sociedades democráticas promoveram mudanças na ordem discursiva: não se aceita a verbalização do olhar discriminatório, sem sanções, em uma escala de reprimendas virtuais à prisão. Dessa maneira, nas palavras de Courtine (2011, p. 256): "Onde quer que se pouse o olhar, a deformidade deve passar despercebida". Nesse contexto, emergem dizeres e imagens que afirmam o respeito à diversidade e à diferença.

Essa nova ordem de discurso pode ser quebrada, por exemplo, em momentos de tensionamento político, especialmente a partir da circulação de narrativas apócrifas, que silenciam a autoria, como nos memes e nas "correntes" que circulam nas redes sociais. Por conseguinte, proliferam discursos estigmatizadores e de ódio, germinados em tempos de intensa polarização político-partidária, como os vivenciados no Brasil a partir das Jornadas de Junho de 2013.
É nesse contexto histórico que emerge a discursivização contrária a Lula. Entendemos que isso é apenas um nó em uma rede de dizeres negativos, como os exibidos nos textos jornalísticos citados.

Em 2010, a revista Trip publicou a reportagem "Um dedo de discórdia" (SILVA, 2018) recuperando a história da lesão trabalhista. A tragédia ocorreu quando Lula trabalhava como metalúrgico, em São Paulo, em meados dos anos 1960. "Uma noite quebrou o parafuso de uma prensa. Eu fiz o parafuso e, quando fui colocar, o companheiro prensista que estava cochilando distraiu-se, largou o braço da prensa, que fechou, e eu perdi o dedo" (SILVA, 2018). Após o acidente, ele recebeu apenas uma indenização "de 350 mil cruzeiros, suficiente para comprar móveis para a mãe e um terreno". A reportagem explica que Lula deixou a fábrica no ano do acidente, depois de discutir por aumento de salário e que foi admitido como "torneiro mecânico" em outra, também na capital do estado de São Paulo.

As marcas do sofrimento permaneceram na subjetividade de Lula: "No hospital, o médico olhou o meu dedo e cortou o resto. Fiquei preocupado com a minha mão. Passei alguns anos com complexo por estar sem dedo. Eu tinha vergonha" (SILVA, 2018).

A narrativa sobre essa ausência é retomada interdicursivamente no meme a seguir (Figura 3):

\section{Figura 3-Meme $\mathrm{CC}_{1}$}

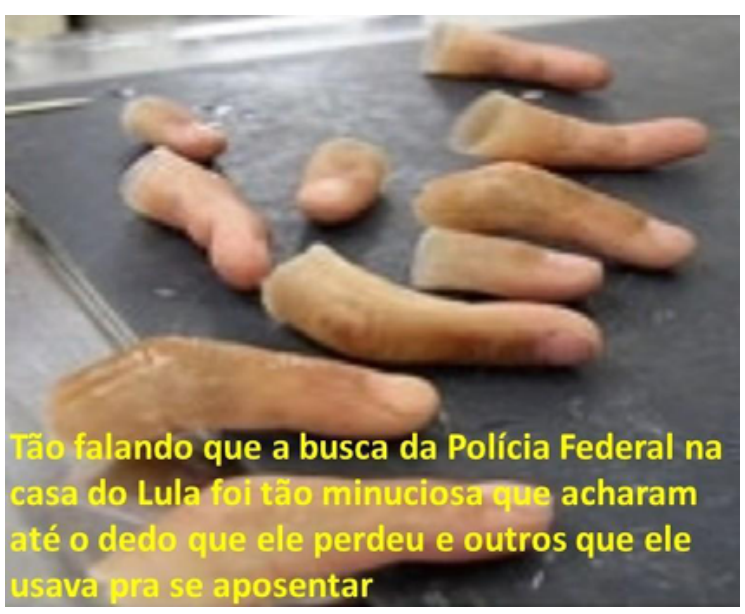

Fonte: Tribuna PR, de 4 de março de 2016. ${ }^{16}$ 
O ingresso de Lula na vida pública aconteceu justamente na filiação ao sindicato dos metalúrgicos onde se tornou um líder na resistência à expropriação do trabalhador por um sistema que impõe "docilidade aos corpos"17, como na metáfora de Foucault (1987).

O discurso do meme é calcado na imagem grotesca, os efeitos derrisórios são causados pela quebra de expectativa: o que se espera encontrar em uma investigação são provas ou indícios de autoria.

Se recorrermos à memória é possivel recuperar também uma série discursos que circulam sobre a mutilação do dedo de Lula. Entre esses, o boato de que o acidente foi autoprovocado para garantir uma aposentadoria por invalidez. Essa discursivização é, dessa forma, retomada no texto verbal do meme.

Ao entrar na política e na esfera da hipervisibilidade, algumas características corporais de Lula se tornaram símbolos identitários: a imagem da mão espalmada com apenas nove dedos é um desses, que retorna na imagem seguinte.

Figura 4 - Meme CC 2

\section{Novo emoji nas próximas atualizações} do Whatsapp

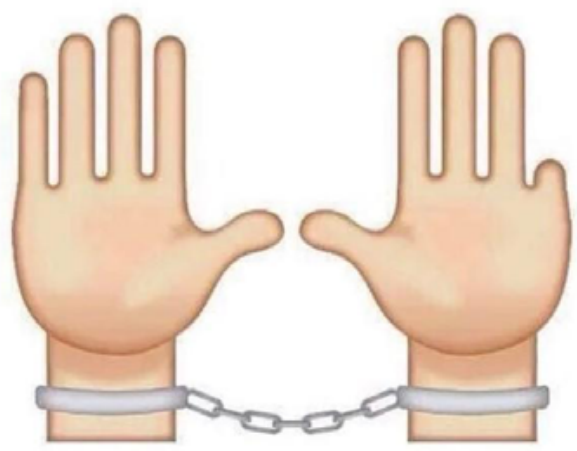

Fonte: Extra Globo, de 4 de março de $2016 .^{18}$
Por vias da memória, é facilmente identificado o referente da imagem. As mãos do presidente, envoltas em algemas, seriam transformadas em um emoji, ideograma esquemático usado em mensagens eletrônicas, especialmente, nos aplicativos de mensagem para celular. Dessa forma, a ausência do dedo mínimo, metonímia do ex-presidente, se tornará um vetor gráfico, ou seja, apenas uma imagem.

Reina a zombaria, silencia a história de resistência que a mutilação de um operário provoca normalmente em outras materialidades da mídia, fotografias e reportagens, por exemplo. Ao contrário da anterior, essa é uma imagem clean, sem impacto, higienizada e sem os vestígios da deformidade.

Em certa medida, retoma-se a discursivização presente no século XIX sobre o monstruoso como inerente à esfera da diversão. Para isso, apaga-se a humanidade, não é uma mão, mas um símbolo. Por conseguinte, constrói-se um efeito de separação da alteridade: esse é o "outro", diferente de "nós". E não há motivos para apreensão. Ele, pois está aprisionado e dominado por uma instituição disciplinar.

Durante a escrita deste artigo, Lula estava há mais de 560 dias preso na sede da Polícia Federal, em Curitiba.

Figura 5 - Meme $\mathrm{CC}_{3}$

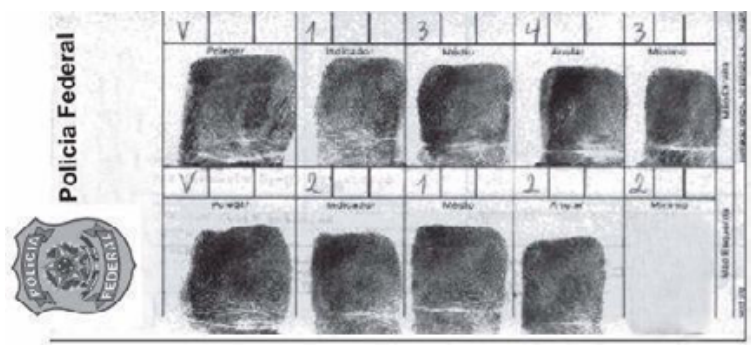

Fonte: Tribuna PR, de 4 de março de 2016. ${ }^{19}$

Ao silenciar os sentidos de dor e de sofrimento provocados por um acidente de trabalho, é possivel rir de uma parte de um corpo que falta. Nessa terceira imagem (Figura 5), há uma suavização da estética grotesca, já que o dedo

\footnotetext{
17 A fábrica é na visão foucaultiana uma dessas instituições que promove o governo dos corpos dos sujeitos, tornando-os dóceis e produtivos.

18 Disponivel em: https://glo.bo/2xPj4ZH. Acesso em: 31 out. 2019.

19 Disponível em: https://bit.ly/2Dlyivt. Acesso em: 31 de out. 2019
} 
ausente não aparece; em seu lugar há o espaço vazio, a lacuna que denuncia a incompletude, uma deformidade não aparente, nos jogos de visibilidade/invisibilidade da imagem.

Efeito diametralmente oposto tem a próxima imagem, em que a estética do grotesco retorna. O enunciado verbal ironiza a condução coercitiva e desconstrói a imagem de Lula, por vias da memória discursiva.

Nela, identificamos o efeito de despersonalização das ações, os sujeitos que encontram o dedo de Lula não são identificáveis. No texto verbal, há um efeito de suavização, estratégia de silenciamento da memória: Lula não teve o dedo amputado no ambiente de trabalho, o que evocaria significações polêmicas no contexto da luta de classes, mas o "perdeu".

Esse silenciamento de um passado já distante ocorre nos movimentos da historicidade. As mãos de Lula passaram por mutações no tempo, as imagens do operário e do sindicalista deram lugar às de um líder carismático capaz de seduzir as massas com "sua voz rouca, com erros de português", retomando o discurso presente em Aquino (2018), conforme a Figura 6.

Figura 6 - Meme $\mathrm{CC}_{4}$

Tão falando que a revista da polícia federal na casa do Lula está sendo tão minuciosa que já acharam até o DEDO QUE ele PERDEU

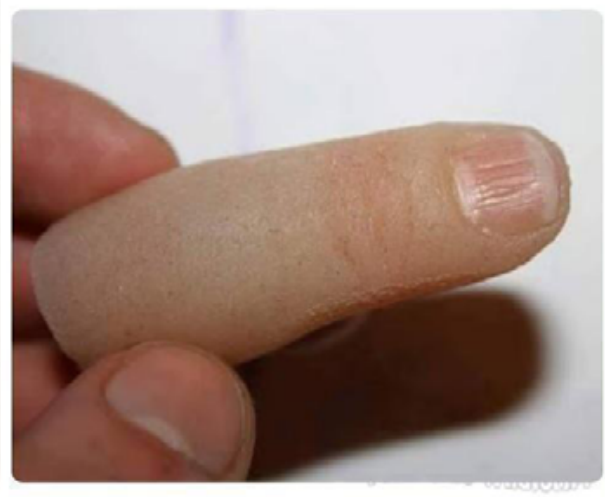

Fonte: Blog Banda B, 6 de março de $2016 .{ }^{20}$
Na última imagem, os efeitos derrisórios são produzidos pela ironia, também com origens no corpo do presidente. A fala de Lula é caracterizada por uma alteração fisiológica chamada de "ceceio", uma flacidez muscular, que impossibilita a produção de alguns fonemas. Retoma-se a imagem da "língua presa" e a sua carga axiológica negativa: Lula não sabe sequer falar, por isso não serve como líder, foi preso.

Além disso, embora todo o aparato jornalístico e o vazamento à imprensa, não foi produzida nenhuma imagem jornalistica da condução de Lula. Essa ausência foi preenchida nos jornais com imagens dos agentes da PF em frente à casa do petista e nas redes sociais foram usadas montagens fakes como a que compõe o meme da Figura 7.

Figura 7 - Meme $\mathrm{CC}_{5}$

\section{LULA é preso por desacato após cuspir na cara do delegado ao tentar falar a palavra 'TRIPLEX'}

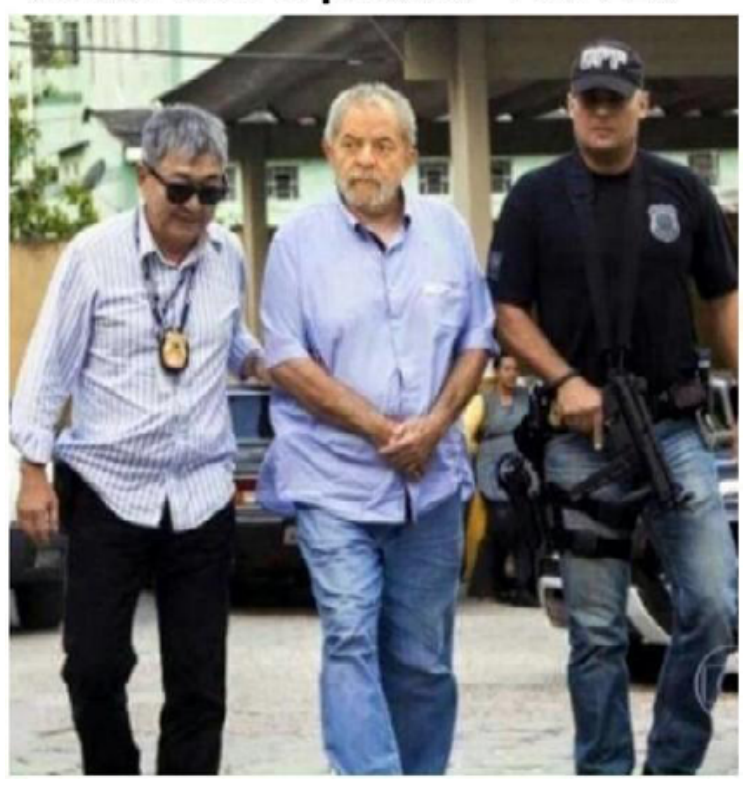

Fonte: Blog Banda B, 4 de março de 2006. ${ }^{21}$

\section{Considerações finais}

As narrativas sobre a Operação Lava Jato produziram a construção de mitos e simplificações: 
o juiz Sérgio Moro, os agentes da Polícia Federal e os procuradores da "República de Curitiba" se tornaram figuras heróicas no combate aos vilões de "colarinho branco". Nesse contexto de crise econômica e política, o presidente Lula e o PT estavam em lado oposto e prefiguravam a corrupção que impedia o crescimento do País.

O dito e o não dito coexistem na superfície das imagens e constroem significações a partir dos jogos de mostrar e ocultar. No movimento discursivo dos memes analisados, observamos o funcionamento de uma das máximas da teoria discursiva: os enunciados adquirem novos sentidos a partir das posições sociais dos que os empregam.

De fato, a voz rouca e as dificuldades de produzir os fonemas, os gestos e a mão mutilada compõem uma identidade e uma imagem reconhecivel e reproduzivel em programas humoristicos e em sátiras. A origem operária do petista será, por vezes, utilizada como argumento negativo pelos detratores e motivo de identificação e engajamento dos lulistas.

No corpus analisado, os memes desconstroem a imagem de Lula graças às suas filiações a formações discursivas opostas ao petista, o campo simbólico das imagens torna-se, dessa forma, uma arena para a confrontação ideológica e disputa de sentidos.

Em certa medida, os memes transformam Lula em um repositório das desqualificações de um individuo que não serve como líder para uma sociedade necessitada de modelos nos quais possa se espelhar como sendo exitosos e bem qualificados. Modelos sem defeitos, cuja ideia de sucesso e liderança possa ser transmitida por uma imagem social clean, não cabendo na figura de um operário amputado e oriundo de família de trabalhadores.

Por fim, advogamos que o discurso dos memes se ancora em uma perspectiva ideológica que refuta os comportamentos, corporeidade e dizeres da classe trabalhadora-operária. Discursos que emergem em um tempo de ruptura com os valores democráticos e de instabilidade política e econômica.

Os memes, enquanto imagens visuais circulam no limiar entre ficção e referencialidade, convertendo imagens sociais em absurdas, risiveis ou grotescas, mesmo quando construídas historicamente, ao longo do tempo como imagens sociais, em personagens que obtiveram a simpatia e a aceitação do meio público e político. Dessa forma, a heterogeneidade discursiva apresenta-se como estratégias derrisórias, como o deboche e a ocultação das qualidades.

O movimento interdiscursivo do meme mostra-se como desarticulador de uma estrutura simbólica em torno de Lula, figura preparada para um campo político como liderança, cuja imagem social tem forte representatividade. $O$ discurso do meme, nessa análise, funciona como uma ação ofensiva sobre um corpo incompleto, marca da anormalidade, permanente motivo argumentativo para uma critica ridicularizada da imagem do ex-presidente.

\section{Referências}

AQUINO, Ruth. Mente aberta. Época, 30 de março de 2012. Disponivel em: http://revistaepoca.globo.com/ Mente-aberta/ruth-de-aquino/noticia/2012/03/voz-de-lula.html. Acesso em: 20 jun. 2018.

BAUMAN, Zygmunt. Modernidade liquida. Rio de Janeiro: Jorge Zahar, 2001.

BLACKMORE, Susan. The meme machine. Oxford: Oxford University Press, 2000.

BLOG BANDA B. Meme CC4. [S. l.: s. n.]: 2016. Disponível em: https://www.bandab.com.br/geral/176708/. Acesso em: 31 out. 2019.

BLOG BANDA B. Meme CC5. [S. l.: s. n.]: [201?]. Disponivel em: https://www.bandab.com.br/geral/176708/. Acesso em: 31 out. 2019.

COURTINE, Jean-Jacques. Decifrar o corpo: pensar com Foucault. Petrópolis, RJ: Vozes, 2013.

COURTINE, Jean-Jacques. O corpo anormal: História e antropologia culturais da deformidade. In: CORBIN, Alain; COURTINE, Jean-Jacques; VIGARELLO, Georges (org.). História do Corpo: 3. as mutações do olhar: o século XX. 4. ed. Petrópolis: Vozes, 2011.

DAWKINS, Richard. O Gene Egoísta. São Paulo: Companhia das Letras, 2007.

DELEUZE, Gilles. Post Scriptum sobre as sociedades de controle. In: DELEUZE, Gilles. Conversações. São Paulo: Editora 34, 1992.

EXTRA GLOBO. Meme CC 2. [S. L.: S. n.]: [201?]. Disponivel em: https://glo.bo/2xPj4ZH. Acesso em: 31 out. 2019.

FOUCAULT, Michel. Vigiar e punir. Petrópolis: Vozes, 1987. 
FOUCAULT, Michel. Os Anormais. São Paulo: Martins Fontes, 2001

FOUCAULT, Michel. A arqueologia do saber. Rio de Janeiro: Forense Universitária, 2005

GOMES, Marcus Alan de Melo. Critica à cobertura midiática da operação Lava Jato. Revista Brasileira de Ciências Criminais, São Paulo, v. 122, p. 229-253, 2016.

HAN, Byung-Chul. Sociedade do cansaço. Trad. Enio Paulo Giachini. Petrópolis: Vozes, 2015.

HJARVARD, Stig. A midiatização da cultura e da sociedade. São Leopoldo: Unisinos, 2014

KUJAWSKI, Gilberto de Mello. O linguajar de Lula. O Estado de São Paulo, 17 fev. 2005, Espaço Aberto, p. A2.

MERCIER, Arnaud. Pouvoirs de la dérision, dérision des pouvoirs. (Introduction) Hermés, Revue. Dérision, contestation, CNRS, n. 29, p. 9-18, 2001. https://doi. org/10.4267/2042/14482.

ORLANDI, Eni Puccinelli. Análise de Discurso: principios \& procedimentos. 8. ed. Campinas: Pontes, 2009.

PAPIRO SÉC. XXI. Meme Lula/Jararaca. [S. l.: S. n.]: 2016. Disponivel em: https://bit.ly/2OJuJ2u. Acesso em: 31 out. de 2019

PRADELLA, Thiago. Leia o manifesto dos Advogados que comparam Lava Jato à inquisição. [S. l.: S. n.]: [201?]. Disponivel em: https://pradella.jusbrasil.com. br/noticias/297190364/leia-o-manifesto-dos-advogados-que-comparam-lava-jato-a-inquisicao. Acesso em: 20 jul. 2018.

REVERBEL, Paula. Grupos pró e contra Lula se enfrentam. Folha de S. Paulo, São Paulo, 05 mar 2016, Poder, p. A11

OLIVEIRA, Felipe Henrique Monteiro. Corpos diferenciados: a criação da performance 'Kahlo em mim eu e(m) Kahlo'. Maceió: EDUFAL, 2013

SHIFMAN, Limo. Memes in digital culture. Cambridge: MIT, 2014. https://doi.org/10.7551/mitpress/9429.001.0001.

SILVA, Marcos Sérgio. Um dedo de discórdia. Disponivel em: https://revistatrip.uol.com.br/trip/um-dedo-de-discordia. Acesso em: 10 ago. 2018.

TRIBUNA PR. Meme CC. [S. l.: s. n.]: 2016. Disponivel em: https://bit.ly/2DlyiVt. Acesso em: 31 de out. de 2019.

TRIBUNA PR. Meme CC 3. [S. l.: s. n.]: 2016. Disponivel em: https:// bit.ly/2Dlyivt. Acesso em: 31 de out. de 2019

VEJA. Capa de Veja. São Paulo, edição 2409, ano 49, n. 11, 16 mar. 2016

\section{Adriano Charles da Silva Cruz}

Doutor em Letras - Linguagens e Cultura, pela Universidade Federal da Paraiba (UFFPB); pós-doutor em Comunicação pela Escola de Comunicação e Artes da Universidade de São Paulo; mestre pelo Programa de Pós-graduação em Comunicação, da Universidade Federal de Pernambuco (UFPE); especialista em Jornalismo Econômico (UFRN) e especialista em Ética (UFRN). Graduado em Comunicação Social - Habilitação em Jornalismo, pela Universidade Federal do Rio Grande do Norte (UFRN). Coordena o Grupo de Pesquisa Cicult -Círculo de Cultura Visual (UFRN/CNPq).

\section{Itamar de Morais Nobre}

Doutor pelo Programa de Pós-Graduação em Ciências Sociais pela Universidade Federal do Rio Grande do Norte (UFRN); pós-doutor pelo Centro de Estudos Sociais (CES), Universidade de Coimbra/Portugal, mestre em Ciências Sociais (Cultura e Representações) pela Universidade Federal do Rio Grande do Norte (UFRN): graduado em Comunicação Social (Jornalismo) pela Universidade Federal do Rio Grande do Norte (UFRN), com especialização em Antropologia.

\section{Endereço para correspondência}

Adriano Charles da Silva Cruz / Itamar de Morais Nobre Universidade Federal do Rio Grande do Norte

Centro de Ciências Humanas Letras e Artes

BR 101, s/n, Campus Universitário

Lagoa Nova, 59072970

Natal, RN, Brasil 